\title{
TRANSITION TOWARDS A CIRCULAR ECONOMY: THE ROLE OF UNIVERSITY ASSETS IN THE IMPLEMENTATION OF A NEW MODEL
}

\author{
Dongxu Qu ${ }^{1,2}$, Tetiana Shevchenko ${ }^{2, \star}$, Michael Saidani ${ }^{3}$, Yuanyuan Xia ${ }^{1,2}$ and Yuriy Ladyka ${ }^{2}$ \\ ${ }^{1}$ Henan Institute of Science and Technology, 453003, China \\ ${ }^{2}$ Sumy National Agrarian University, 40021, Ukraine \\ ${ }^{3}$ Laboratoire Genie Industriel, Université Paris-Saclay, CentraleSupélec, 91190, France
}

Article Info:
Received:
5 April 2021
Revised:
9 July 2021
Accepted:
1 October 2021
Available online:
16 December 2021
Keywords:
Circular activities
Circular economy
Consumer behavior
Public awareness
Transformative learning
University assets

Article Info:

Received:

9 July 2021

16 December 2021

Keywords:

Circular activities

University assets

\begin{abstract}
Public awareness and relevant consumer behaviors are crucial in accelerating the transition to a circular economy (CE) model. This paper focused on exploring university activities for changing awareness and behaviors according to the principles of its new circular model to foster sustainable development. In this paper, a comprehensive literature review provides a holistic perspective on university CE-related activities in the implementation of the $\mathrm{CE}$. The review revealed that the construction of a theoretical framework in universities with asset-based development is conducive to promoting the CE model through transformative learning. In light of recent academic insights into CE education, a theoretical framework for CE-related university activities was developed based on attributes of CE-related university assets, such as non-profit status, technology innovation, education, propagation, and efficient use of resources. We also introduce into scientific use the term CE-related university assets and provide a classification of these CE-related assets. The present findings contribute to a deeper understanding of universities' CE-related resources and assets to improve public awareness and behaviors, as well as to train and inspire the leaders (including engineers, managers, designers, etc.) of tomorrow, required for further implementing the CE model.
\end{abstract}

\section{INTRODUCTION}

Today, the circular economy (CE) model is increasingly recognized in many countries throughout the world as a sustainable alternative to the traditional linear model because of the CE model's contributions in sustainability with fewer resources consumed and lower environmental pollution (Zhang et al., 2019). Interestingly, the implementation of CE practices can support the achievements of several sustainable development goals (Schroeder et al., 2019). Since the 1970s, Germany (Shen, 2016) and other members of the European Union (Wysokińska, 2016), Japan (Liu \& Du, 2019), the United States (Hu \& Ji, 2017), Britain (Qiao \& Wang, 2013) and many other countries have carried out practical explorations of the CE. After it was officially introduced in China in the late 1990s, the concept was generally accepted by all sectors of society and elevated to be a national development strategy (Ma, 2016). It is evident that although the CE has been implemented according to the federal law for years and provides numerous benefits, there is still a huge gap between theoretical research and practical processes (Shevchenko \& Kronenberg, 2020; Zhai, 2017). To promote the implementation of the $\mathrm{CE}$, many researchers have examined the drivers of and barriers to the $\mathrm{CE}$, which could accelerate or derail the move to this new model (De Jesus \& Mendonça, 2017). Generally, the government, enterprises, and the public are regarded as the three primary stakeholders in promoting the CE model (Dong et al., 2016). However, during the past decade, the implementation of the CE in China has been driven mainly by top-down promotion by the government. The Chinese government has not been satisfied with the implementation effect of CE policies because of the insufficient participation of stakeholders other than the government (Liu, 2014). In fact, the stakeholders that promote CE performance must be diversified and work together to prevent the implementation of CE from coming to a standstill (Gaidabrus et al., 2014; Telizhenko et al., 2016). Bottom-up promotion by the public has recently attracted researchers' attention; the main stakeholders are enterprise operators that pursue economic benefits and citizens who pursue ecological benefits (Zhu, 2017). Nevertheless, the public generally lacks CE awareness and behaviors (Guo et al., 2016; Shevchenko et al., 2019), while enterprise operators have insufficient CE-related knowledge and are unwilling to pay the high costs of implementation of the CE (Liu, 2015). 
Therefore, it is crucial to promote CE awareness and behavior by the public through effective CE education in transitioning to a CE model.

Higher education institutions have a particular social responsibility for the development of society, particularly in the proliferation of public awareness of sustainability, and in the training of future workforce in this topic (Amaral et al., 2015; Findler et al., 2019). The functions of higher education institutions, namely, the trinity of talent cultivation, scientific research, and social service, also determine that universities are one of the effective driving forces for promoting the bottom-up transition toward the CE model (Qu \& Shevchenko, 2019). Moreover, the Circular Economy Development Strategy and Action Plan (PRC SC, 2013) and the Circular Economy Promotion Plan 2015 (PRC NDRC, 2015) explicitly stipulated the position and responsibility of higher education institutions in the implementation of the CE. However, the theoretical foundation of the development of higher education institutions in light of all possible circular activities and relevant assets is limited. To bridge this gap, this paper aims to carry out a systematic analysis of Chinese universities' activities contributing to the CE to propose a theoretical framework of university CE-related activities, so as to inspire commendable practices from one university to another as well as find a breakthrough to accelerate the CE transition in China.

In this paper, an extensive review of CE-related activities at the university level was conducted and has led to the need to construct a theoretical framework of CE activities with assets as the core for universities in the process of implementing the CE. To ensure that the review was comprehensive, articles published in the top-tier periodicals and peer-reviewed journals over the last 20 years in English and Chinese were selected. The literature was retrieved via Scopus, Web of Science, Google Scholar, and CNKI search engines based on the following keywords: "circular economy", "implementation model", "circular economy education", "circular economy practice", "stakeholder", "driving force", "barriers and challenge", "environmental education", "public awareness", "circular behavior" and "university assets". In addition, other papers and monographs were discovered from the references of selected articles based on relevance to the topic and popularity in terms of citations. A qualitative research method, informed by a critical literature review adopted from Ranjbari et al. (2021), is employed in this research to develop a theoretical framework for CE-related university activities based on attributes of university assets, such as non-profit status, technology innovation, education, propagation, and efficient use of resources.

\section{LITERATURE REVIEW}

\subsection{Transformative learning theory and university CE activities}

Studies of CE activities in colleges and universities include benefit analysis of the introduction of recyclable materials and recycling systems on campus (Barros et al., 2020; Tan \& Li, 2016), the design of sustainable resource management schemes (Salguero-Puerta et al., 2019; Wil- liams \& Powell, 2019) and other applications of CE principles in campus development (Hopff et al., 2019; Mendoza et al., 2019). Among them, CE education in universities is expected and has been considered one of the most pivotal factors to realize the transition toward the CE model (Bugallo-Rodriguez \& Vega-Marcote, 2020). CE specialty education and general education in universities have been a broad concern for researchers, involving the establishment of talent training mode (Cui et al., 2018; Weissbrodt et al., 2020), construction and evaluation of the CE curriculum system (Kirchherr \& Piscicelli, 2019; Nunes et al., 2018; Rodriguez-Chueca et al., 2020), and CE education in specific fields (Kopnina, 2019; Rokicki et al., 2020). Moreover, China has incorporated the construction of a CE major and the cultivation of CE professional talent in universities in the national overall development strategy in recent years, which have led to some achievements (Qu et al., 2020).

However, university CE activities are fragmented and disconnected from each other and lack a system that can integrate them for an augmented effect. Moreover, there is no necessary correlation between higher education performance and sustainable behavior in society (Orr, 2002). Therefore, if universities want to improve the efficiency of the implementation of the $C E$, it is necessary to cultivate and pursue $\mathrm{CE}$ values and mindset that can completely change the inherent thinking and operation patterns of the linear economy. To this end, transformative learning is a credible alternative to solving this problem, because the effect in the field of adult education has been proven (Sokol \& Shaughnessy, 2018). Furthermore, the significance of transformative learning in Education for Sustainable Development (ESD) has also been confirmed (Burns, 2018). Transformative learning implies profound structural changes in the basic premises of thought, emotion and behavior, and such a change in consciousness would dramatically and permanently alter self-cognition and our way of being in the world (Sterling, 2010-2011). In other words, different from the traditional manner of knowledge imparting and idea instilling, the CE concept and values can be internalized in the mind and manifested in practice through transformative learning.

To better understand the connotation of transformative learning, Bateson's hierarchy theory of learning should be reviewed. According to Bateson, learning should be separated into three levels, embracing learning, meta-learning, and epistemic learning (Blake et al., 2013). At present, the formal education implemented by higher education institutions generally advocates the first level of learning, which aims to improve intelligence by imparting knowledge through transmissive pedagogy (O'Neil, 2018). Meta-learning refers to the critical assessment and inspection process of the connotative ideas behind the learning content, which could cause changes in the beliefs and values of the subjective world. Epistemic learning is the process of thoroughly reconstructing the paradigm of learners, which will bring changes in people's worldview and the way they get along in the world. The three learning levels range from low to high, where the higher-level learning experience affects the mindset and action of lower-level learning; see Figure 1. The first level of learning is far from sufficient 


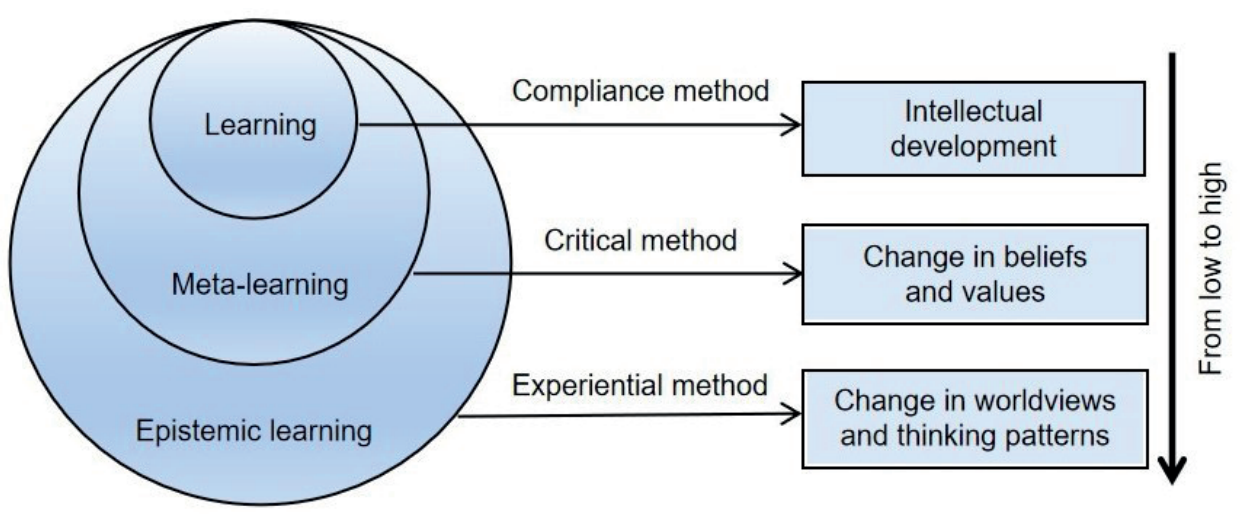

FIGURE 1: Hierarchy of learning and the transformation of different levels.

to establish CE values and patterns for improving the performance of CE education in universities. Higher levels of transformative learning and education are needed to improve the quality of CE education in universities, which not only could help learners acquire knowledge but also make them internalize CE values in their worldview and epistemology to stimulate the natural occurrence of pro-circular behaviors. With the combination of theoretical learning and practical experience, constructing a systematic CE theoretical framework in universities is a significant approach to realize transformative learning and education, which could integrate various isolated CE activities, thus enabling university administrators and students to change their epistemological presupposition and behavioral patterns to make the universities' effect truly prominent in promoting the implementation of the $\mathrm{CE}$.

\subsection{Development of university ESD and CE theoreti- cal framework}

Since the concept of sustainable development was first put forward in 1987, the international community has explored how to make education a supporting factor in sustainable development. Along with the continuous promotion of a series of activities, such as Agenda 21 (SDGKP, 1992), the United Nations Decade of Education for Sustainable Development (2005-2014) (UNESCO, 2003), the Global Action Programme on Education for Sustainable Development (2015-2019) (UNESCO, 2014) and the Education 2030 Framework for Action (UNESCO, 2015), ESD in universities has gradually formed systematic implementation and evaluation models. The most influential ones are the College Sustainability Report Card (CSRC) (ASEI, 2011) and the UI GreenMetric World University Rankings (UIGWUR) (UI, 2019), both of which concentrate on ranking or grading universities that strive to contribute to sustainability by evaluating their contributions to sustainable development to encourage universities' efforts to achieve the United Nations' Sustainable Development Goals (SDGs). The CSRC published by the American Sustainable Endowments Institute aims to grade the sustainability profiles of 322 colleges and universities in the United States and eight Canadian provinces in accordance with nine classification indicators. The UIGWUR, launched by Universitas Indonesia in 2010, has been widely recognized as the most authoritative assessment of sustainability efforts for universities all around the world. This tool mainly conducts an online survey and ranks the 912 participating universities in terms of their efforts at sustainability and policies through 6 classified indicators. The indicator categories of evaluation are shown in Figure 2.

Moving toward a CE model is one of the crucial approaches for delivering the SDGs (Schroeder et al., 2019). Therefore, a university CE theoretical framework should be established within the category of university sustainable development strategy. The analysis of the evaluation indicators above reveals that these sustainability implementation and evaluation systems contain many CE ideas and activities, which are a significant theoretical basis for forming a specialized CE theoretical framework for universities. The indicators and content of these systems that do not match the CE theoretical framework precisely reflect the disparity between them. In essence, the biggest disparity is mainly the difference between the concepts of sustainable development and CE. Sustainable development is a scientific development path that concerns the three-dimensional harmonious coexistence of economy, society and ecological environment. Therefore, the intentions of ESD are to promote the realization of the 17 SDGs by exerting the function of education in three levels below. The first level is to make the transition to a sustainable economic growth model, such as decent work and economic growth (SDG 8). The other is to foster the harmonious development and progress of society, such as no poverty (SDG 1) and zero hunger (SDG 2). The third level is to preserve and recover the ecological environment, such as climate action (SDG 13) and life under water (SDG 14).

Compared with the grandiose concept of sustainable development, the concept of CE is relatively concrete and realistic, which is viewed as an operationalization of sustainable development (Murray et al., 2017; Saidani et al., 2017). To the best of our knowledge, $C E$ is a new economic system that replaces the "take-make-waste" linear model with the "cradle to cradle" concept in the whole life cycle of materials (Shevchenko et al., 2021) by reducing, alternatively reusing and recycling (3Rs) the resources and assets in the process of production and consumption (Ghisellini et al., 2016), aiming to decouple economic growth from finite resource consumption and environmental degrada- 


\section{College Sustainability Report Card}

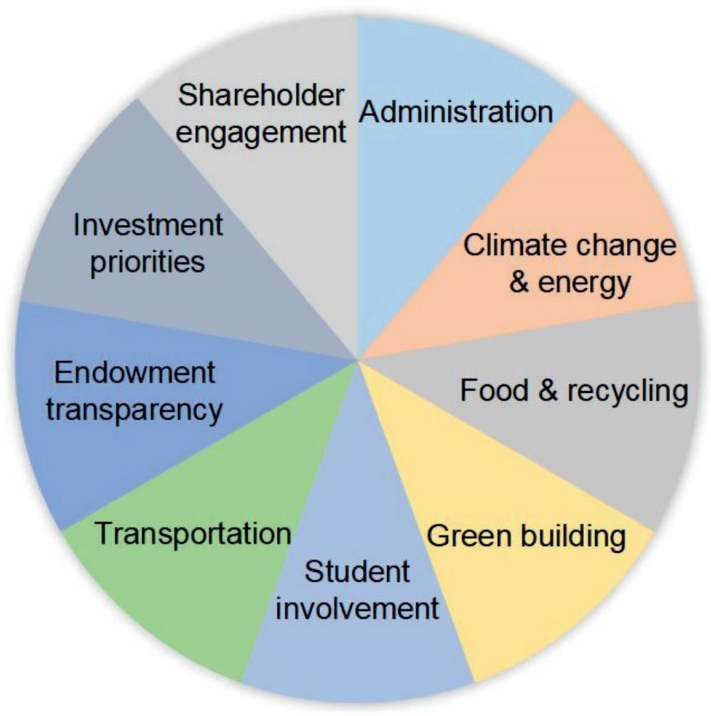

UI GreenMetric World University Rankings

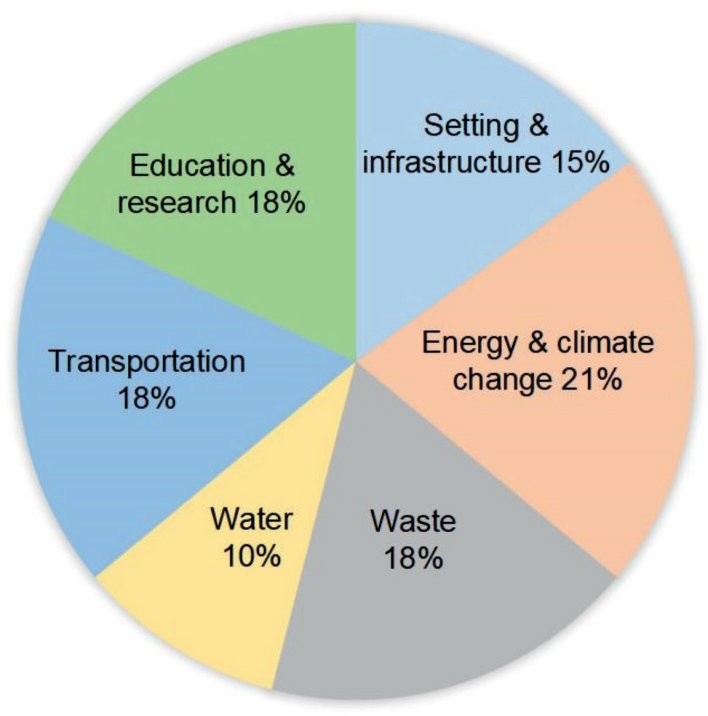

FIGURE 2: Indicator categories of the College Sustainability Report Card and the UI GreenMetric World University Rankings.

tion by reducing waste and maximizing resource utilization (EMF, 2021). Thereinto, the 3Rs are the dominant principles among the CE principle ranged from $3 R$ s to 10 Rs in the previous literature (Reike et al., 2018; Saidani et al., 2019), from which three cyclic processes that run through the CE framework could be extracted (Morseletto, 2020). The first is the service cycle based on the Reduce principle. That is, by investing in a CE-oriented human capital support system, the top-level design and value reconstruction of $\mathrm{CE}$ service could be realized so as to reduce or even avoid the use of unnecessary resources to cut down the occurrence of new waste, for example, the CE training for educators, the Empty Plate Campaign launched in the campus canteens and the Plastic Limit Campaign initiated among student consumers. The second is the material cycle based on the Reuse principle. The material capital could be allocated efficiently to realize the most reasonable utilization of all materials through the transfer or sharing of the ownership or right to use of the resources, such as integrating idle bicycles to set up the shared cycling system on campus, transferring the ownership of idle office furniture and providing rental services for unused spaces such as classrooms during holidays. The third process is waste recycling based on Recycle principle. The valuable materials in the waste could be recycled and remanufactured to give new life to the materials to improve the utilization efficiency, such as establishing the domestic garbage sorting system and cartoon waste recovery system. In other words, the CE framework should focus on the goals of improving the utilization efficiency of resources and assets and reducing waste through the input of human capital and the diversified allocation of physical capital. In general, the university CE theoretical framework should be based on the overall layout of sustainable development for the university, aiming at ensuring the long-term implementation of the SDGs (Schroeder et al., 2019) by considering the most rea- sonable use of resources and environmental sustainability.

Furthermore, there is little participation in the UIGWUR by Chinese universities because the establishments of sustainable university are still in the initial stage in China. Many Chinese universities currently have no dedicated department responsible for implementing ESD or the CE to coordinate and organize these actions. Therefore, Chinese universities need to combine with their own characteristics to construct a systematic CE theoretical framework, rather than passively wait for all conditions to be mature before putting it into action. In this paper, the CE theoretical framework we propose based on CE-related university assets conforms to the realistic setting and practical convenience in China and could stimulate multiple subjects to make subjective initiatives, which is conducive to promoting the process of constructing sustainable universities and the realization of SDGs in universities.

\section{RESULTS}

\subsection{CE-related university assets: definition and at- tributes}

To better describe the CE theoretical framework for universities, we provide a definition of the university assets by considering the discourse on the CE (Kirchherr et al., 2017; Rossi et al., 2020) and the concepts of assets (Zhang et al., 2020; Ma, 2020). We define CE-related university assets as all types of resources that formed during the course of the university's development, owned or actually controlled by the university, and are expected to facilitate the transition to a CE model in the use process. CE-related university assets are the basis for universities to implement various CE activities, and an important indicator for measuring and evaluating a university's CE performance. Specifically, this novel concept contains four basic elements. The first is that the ownership subject of the CE-related university assets is the university. The second is that the forms of 
the assets are diverse. Examples include tangible assets, intangible assets, and fixed assets. The third is that the use process of the assets should follow the 3Rs principles of the CE. The fourth is the orientation of the assets should include universal CE policy goals.

Compared with other university assets, we argue that there are unique characteristics exclusive to CE-related university assets, including non-profit status, technological innovation, education, propagation and efficient use of resources. All of these attributes are significant factors for achieving the goals of a $\mathrm{CE}$, see Figure 3 .

- Non-profit attribute. It is stipulated that no organization or individual may establish educational institutions for profit in China (PRC MOE, 1998). Different from enterprises and other entities pursuing the goal of profit maximization, universities mainly focus on social benefits and public services as their ultimate goal. Therefore, CE-related university assets are non-profit.

- Technology innovation attribute. As one of the main execution subjects of research and development (R\&D) activities in China, universities have a significant number of research teams, experts, scholars, and postgraduate students, who promote the vigorous development of scientific research assets in universities (Yin \& Shen, 2005). It is evident that universities are the dominant contributors to the national scientific and technological output and achievements.

- Education attribute. Universities are significant bases for cultivating talent, which have abundant educational assets such as lectures and other teaching resources. These tangible and intangible educational assets could cultivate and transport a significant amount of talent for the society, and bring in a large number of practitioners with CE values and professional CE talent for various sectors of society. Also, CE practice in universities has an implicit education effect on students.

- Propagation attribute. Higher education institutions have great social influence in spreading culture and values, and their propagation activities for the values and value judgment could directly affect the thoughts, attitudes and behaviors of members of society (Zhao \& Zhang, 2012). Universities can disseminate pro-circular values to society through lectures, teaching activities, students' social practice and volunteer service activities, and graduate employment in various industries.

- Efficient use of resources attribute. The essence of the CE model is to improve the efficient use of resources to achieve the goal of coordinated development of environmental protection and economic development. CE-related university assets are oriented by efficient use of resources; for example, textbook recycling and a paperless office system could improve the rate of resource utilization and reduce resource waste.

\subsection{Classifications of CE-related university assets}

To further clarify the extension and the specific orientation of CE-related university assets, we establish a multi-dimension classification system according to different features. This system is beneficial for decision makers to have a better understanding of the various categories and usage rules of CE-related assets, so as to conduct top-level scientific design and better propel the CE practice on campus. It could also help the participants of CE activities to cotton on the range of $\mathrm{CE}$-related assets from multiple perspectives

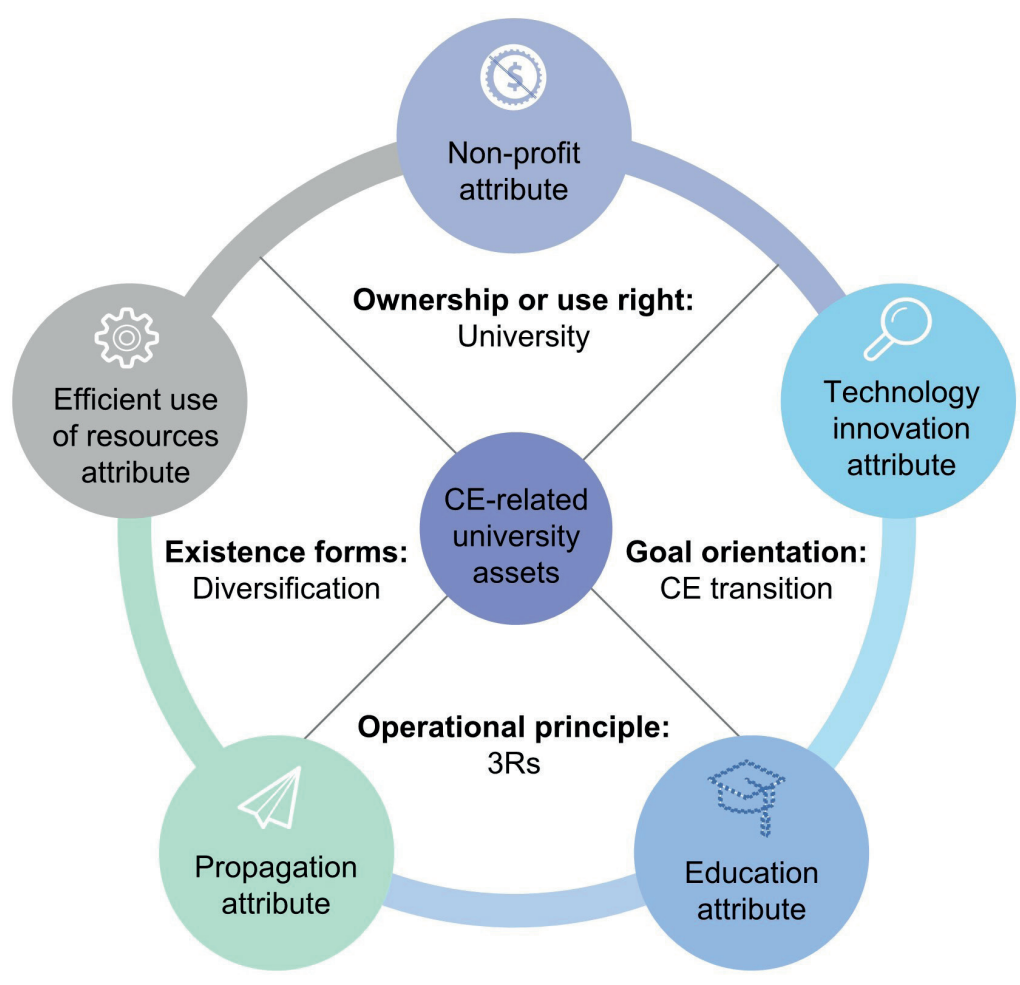

FIGURE 3: The elements of CE-related university assets. 
TABLE 1: The classification of CE-related university assets.

\begin{tabular}{|c|c|}
\hline Classification feature & Types of CE-related university assets \\
\hline By application & $\begin{array}{l}\text { 1. Scientific research CE-related assets } \\
\text { 2. Education CE-related assets } \\
\text { 3. Operations CE-related assets }\end{array}$ \\
\hline By morphology & $\begin{array}{l}\text { 1. Tangible CE-related assets } \\
\text { 2. Intangible CE-related assets }\end{array}$ \\
\hline By formation method & $\begin{array}{l}\text { 1. Innate CE-related assets } \\
\text { 2. Developed CE-related assets }\end{array}$ \\
\hline $\begin{array}{l}\text { By cost level in the imple- } \\
\text { mentation of the CE }\end{array}$ & $\begin{array}{l}\text { 1. High-cost CE-related assets } \\
\text { 2. Low-cost CE-related assets }\end{array}$ \\
\hline $\begin{array}{l}\text { By method of participating } \\
\text { in the } \mathrm{CE}\end{array}$ & $\begin{array}{l}\text { 1. Direct CE-related assets } \\
\text { 2. Indirect CE-related assets }\end{array}$ \\
\hline
\end{tabular}

so that they could be able to clarify their responsibilities and striving direction in CE implementation. We argue that CE-related university assets can be classified into different types based on different standards; see Table 1.

First, according to the application, we propose to classify CE-related university assets into scientific research, education, and operations CE-related assets. Scientific research CE-related assets refer to scientific and technological support that can provide green and innovative technologies for the implementation of the CE through research and the integration of production, education and research. Education CE-related assets are educational resources that can cultivate CE professional talent for the national CE strategy, as well as improve CE awareness and knowledge of college students and the public. Operations CE-related assets are the physical campus resources that can be explored in CE practice that are managed by universities' operations departments, for instance, the development of shared cycling systems on a university campus. A large number of idle bicycles due to different reasons, such as abandoned by graduates, could be regularized and conducted with scientific management by the university logistics department to establish a free shared cycling system on campus. This system that reflects the attributes of CE-related assets could not only avoid the consumption of new bicycles to reduce resource waste but also realize the refurbishment and reuse of idle bicycles to improve the efficiency of resource utilization, see Figure 4.

In addition, we propose that CE-related university assets should be classified into innate and developed CE-re- lated assets in line with different methods of formation. Developed CE-related assets must be created, developed or transformed artificially in a later use stage to meet the needs of the CE transition, such as research and creation of green materials and green products, and exploitation and construction of the CE curriculum. Different from developed CE-related assets, innate CE-related assets are assets that are pro-circular in the early stage of introduction or purchase, whose nature does not need to be acquired through post-processing and creation, such as green office supplies and textbooks and learning materials. Specifically, books and learning materials have distinct characteristics that include easy to preserve, high durability, easy to identify (unique ISBN code), so the second-hand book trade is always regarded as a typical representative of CE practice. Universities could apply the technical means to establish a free internet second-hand book trading platform for teachers and students with the adoption of a more flexible C2B2C (Customer to Business to Customer) model, so as to realize the reuse of books to improve the utilization efficiency. Meanwhile, CE information and ideas could be spread through this learning material recycling system to attract more users to participate in the recycling activities, see Figure 5.

Based on the morphology, we suggest dividing CE-related university assets into tangible and intangible CE-related assets; that is, the former has physical forms, while the latter is invisible. Intangible CE-related assets are unique non-physical resources, which can be used for personnel training, scientific research and external exchanges, including technological knowledge assets, human resources assets, institutional assets, reputation assets and other types.

Furthermore, we argue that CE-related university assets should be divided into high- and low-cost CE-related assets based on the costs of the CE-related assets involved in promoting the transition to the CE model. High-cost CE-related assets require universities to spend a certain amount of time and money or effort when developing this type of asset, for example, the construction of a bicycle sharing system and a reclaimed water recycling system. Low-cost CE-related assets do not cost too much time, money or effort, or are too inconvenient or even provide good benefits, such as the development of general CE education or recycling of learning materials.

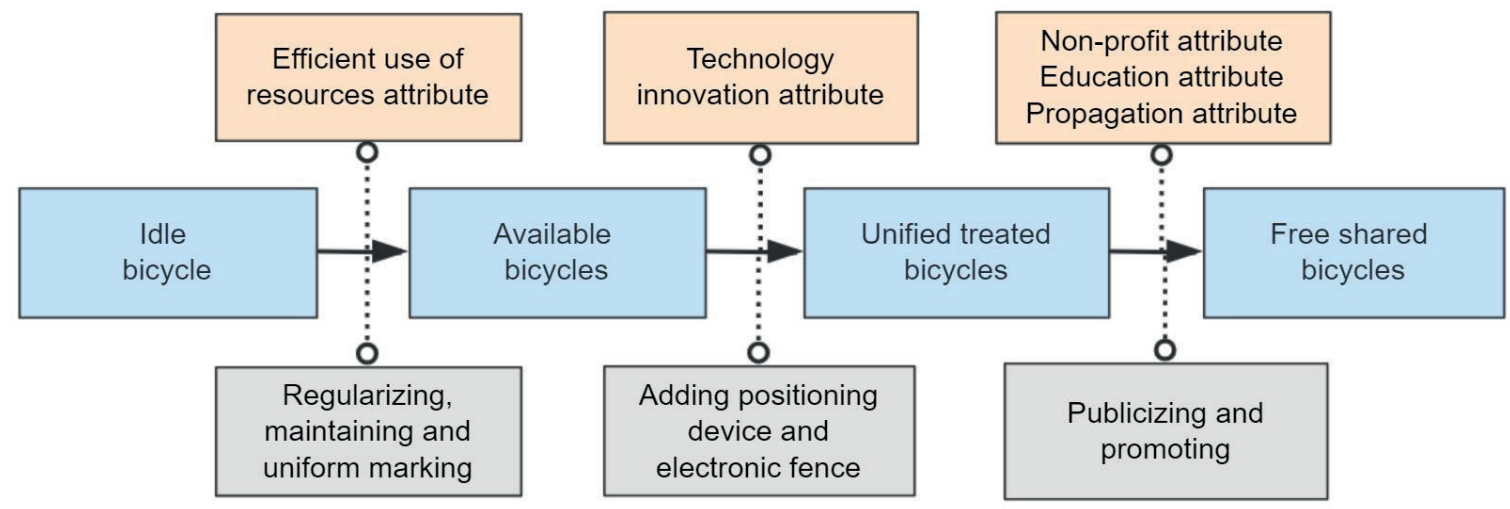

FIGURE 4: Flow diagram of the establishment of shared cycling system in university. 


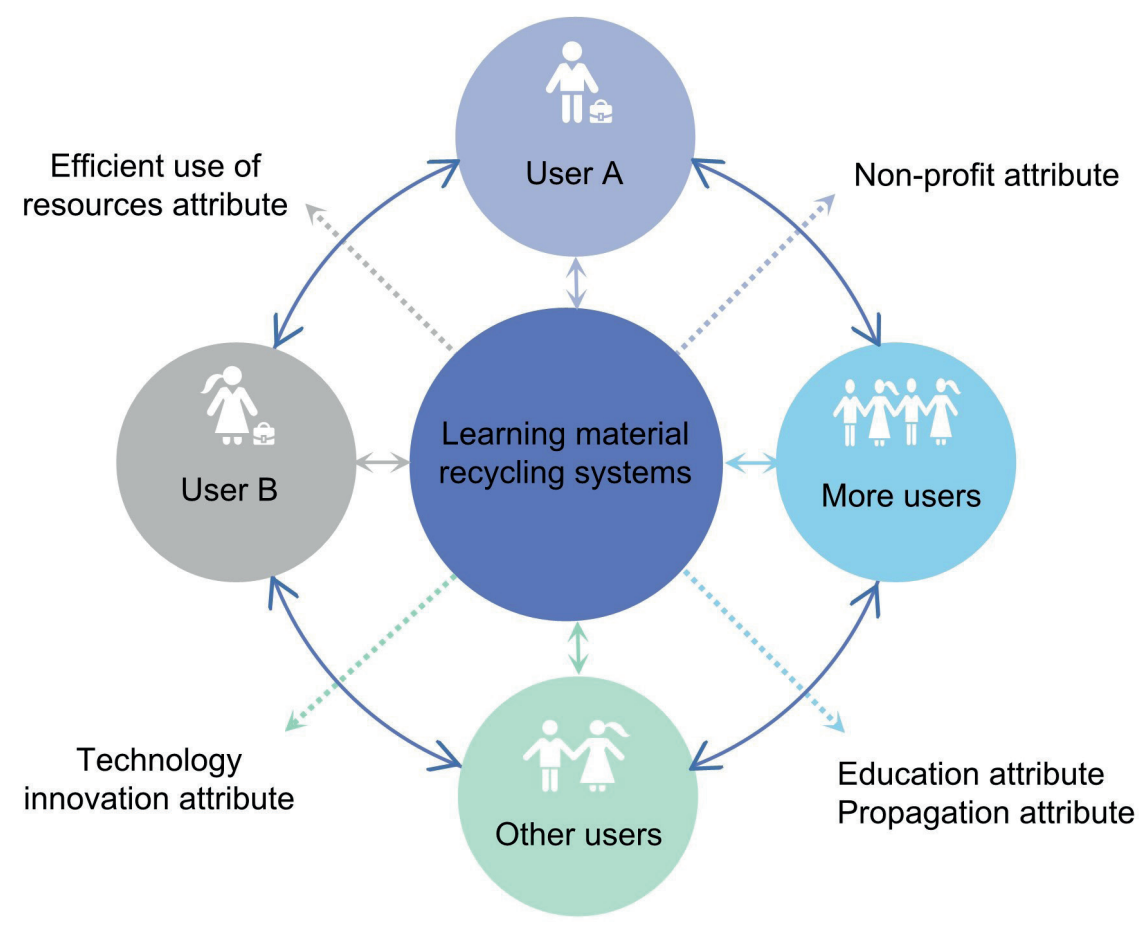

FIGURE 5: Learning material recycling system based on the internet trading platform.

Last, in terms of the different ways of promoting CE performance, we categorize CE-related university assets into direct and indirect CE-related assets. The former directly participates in or promotes the implementation of the CE, such as the CE practice carried out by the asset management department and the operations department. The latter is not directly involved in the implementation of the CE but can provide essential elements that can promote the implementation of the $C E$, such as educational assets that can improve people's CE awareness and knowledge. For instance, universities could cultivate CE professionals and implement general education about $\mathrm{CE}$, and then students with professional knowledge and ideas can promote the implementation of the CE through their various pro-circular behaviors.

\subsection{Content of CE-related university activities}

Based on the definition and characteristics of CE-related university assets, CE-related university activities refer to the movements or actions that a university carries out to contribute to the transition toward the CE model with CE-related assets as the core. The essence of CE-related university activities includes scientific research, education and concrete practical activities based on the classification of CE-related assets by application, as shown in Figure 6 .

Scientific research activities mainly focus on the research and application of CE technology, including research on green materials and green technology by researchers at the university and the transformation of green science and technology achievements from theory to practice through university-enterprise cooperation. China is making green technological progress the main driving force for sustainable development in the future (Jing \& Zhang,
2014). Researchers have shown that the effect of guiding R\&D toward green technology is significant in promoting the progress of green technology (You \& Wang, 2016). In 2019, China invested 23.13 billion euros in R\&D at higher education institutions, an increase of $23.2 \%$ from 2018 and accounting for $8.1 \%$ of the total expenditure. The proportion of the scientific and technological output of higher education institutions is much higher than the proportion of appropriation expenditure on R\&D (NBSC, 2019). As the dominant contributors to the national scientific and technological output and achievements, universities can provide the necessary green technology support for the transition to the CE model by guiding researchers toward green technology innovation. Additionally, the application and transformation of green technological achievements are as important as the research on green technology. That is, achievements with practical value generated in the university laboratory should be put into practice for subsequent test, development, application and popularization. Cooperation between universities and industries is vital to realize the transformation of green technological achievements. With the increasingly common research on the coordinated development of green technology and economy, the combination of the scientific research advantages of universities and the industrial carrying capacity of enterprises can effectively promote the implementation of the CE to close the gap between theory and practice.

Educational activities mainly refer to the education and dissemination of the CE concept to students as well as society, which includes the cultivation of CE professionals and graduates with CE values for society, and the dissemination of the CE idea to the public. In 2019, there were 2,688 general higher education institutions, with a total of 


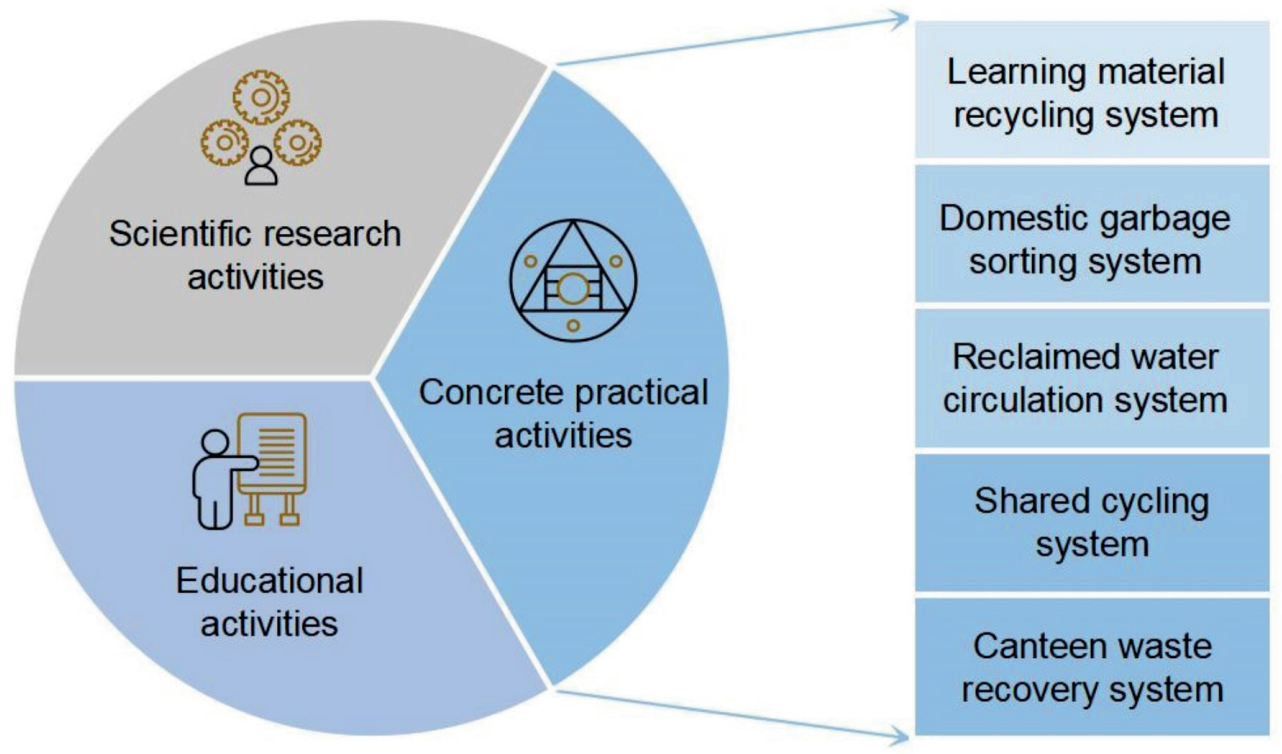

FIGURE 6: Illustrative content of the key types of CE-related university activities.

1.74 million full-time teachers, 30.315 million students and 7.585 million graduates at the undergraduate level, and 2.863 million students and 0.64 million graduates at the postgraduate level (NBSC, 2019). Colleges and universities play an irreplaceable role in environmental education by offering sustainability courses in a wide range of disciplines and departments (Coleman \& Gould, 2019). However, according to the list of newly registered undergraduate majors published by the Ministry of Education every year, until 2019, only 49 colleges and universities in China offered a Resource Recycling Science and Engineering major, an emerging major approved by the Chinese Ministry of Education in 2010 to meet the urgent demand for talent in the implementation of the CE strategy in China (Qu et al., 2020). To solve the problem of the shortage of CE professionals, universities could attach importance to CE training for educators so that they could effectively convey the correct CE message by their course teaching. Moreover, it is necessary to strengthen the structure of the CE major and formulate scientific curriculum training programs to improve the training of CE talent. The graduates with CE degrees hired by enterprises can bring sufficient CE concepts and creativity to enterprises. Moreover, general education could be universalized to cultivate undergraduates with $\mathrm{CE}$ awareness and knowledge, who can spread CE values to surrounding communities through social practices in the community and guide residents to form green consumption habits. Graduates with CE awareness and knowledge are potential green consumers and CE practitioners, who can also disseminate CE values in their areas of expertise and their daily lives after they graduate.

Concrete practical activities refer to concrete CE practices on campus which consist of various resource recycling systems for achieving the $\mathrm{CE}$, as well as direct use of a university's CE-related assets. Taking learning resources as an example, a survey of Wuhan University of Technology students showed that $85.6 \%$ of the respondents disposed of these post-use learning resources as waste paper rather than recycling them as reusable textbooks (Du, 2016). To advocate for recycling and reuse of textbooks and other learning materials, universities could organize on and offline learning material recycling systems (Guo, 2014). In addition, various resource recycling systems could be established on campus, such as a domestic garbage sorting system, a reclaimed water circulation system, a shared cycling system and canteen waste recovery systems. Additionally, an internal CE-related assets management network could be set up to monitor the efficient use of assets at every stage of their lifecycle according to CE principles. From the purchase of assets as a starting point, priority could be given to the use of environmentally friendly materials and products. In the process of using such products and processes, it is necessary to fully consider whether they pollute the environment and how to control pollution and other negative factors. The possibility of multi-level recovery of waste and other related factors would be considered in the process of asset scrapping and waste recovery. These both concrete and practical activities could exert an edifying influence on leaders and students and contribute to the realization of transformative CE learning and education.

\subsection{Proposed framework to support the implemen- tation of CE-related university activities}

CE-related university activities involve a wide range of areas, including scientific research, education, undergraduate social practice and operations, so the subjects of CE-related university activities are more extensive, which means all university members need to be the subject of CE-related activities. Therefore, the CE theoretical framework would include all university members with wide spread knowledge as the key to successfully disrupting the linear system. In particular, the subjects mainly include researchers and lecturers of relevant teaching departments, undergraduate social practice departments and students with CE awareness and knowledge, as well as the operations department and its staff. It should be noted that not all uni- 
versity staff are born with the CE knowledge and ability to carry out CE-related activities, so CE training for them is the precondition for the implementation of all kinds of CE-related activities in this framework. On this basis, university researchers could take advantage of scientific research, set up teams to carry out CE policies and theoretical research, focus more on green technology design and technological innovation, and breakthrough the existing bottleneck of CE technology. Through curriculum teaching activities, lecturers could aim to cultivate CE professionals for enterprises and college students with CE awareness and knowledge who could disseminate CE education to society with routine social practices. In addition, operations managers and staff could explore CE practices on campus by constructing resource circulation systems and monitoring their operations. This practical exploration not only provides a direct and effective reference to the implementation of the CE in society but also affects the public's lifestyle in an all-around way, and forms the ecological culture within universities, thus contributing to the formation of a good ecological culture for society.

Based on the elaborations above, this paper proposes the theoretical framework of CE-related university activities that could provide many benefits for promoting the $\mathrm{CE}$ transition, including the construction of the CE culture in society, green manufacturing and technological innovation in enterprises, green consumption and participation in supervision of the public, see Figure 7.

In this framework, the subjects of CE-related university activities are the major factors, because their attitude and behaviors directly determine the effect of CE-related activities. Therefore, the CE training for university faculty and staff is of great significance. Fortunately, there is no need to impose excessive coercion or inducement for them except the training, because scientific research and teaching are crucial parts of universities' routine work. All they need to do is to integrate CE information into their daily work. Moreover, it is very convenient and effective to spread CE concepts to community residents by taking student social practice activities as an opportunity to implement education, because social practice activities during vacations and daily volunteer social service activities at every university in China has become a tradition (Wang, 2014). In addition, implementing CE practices on campus requires only the operations department to adjust the working concepts toward the goal of the CE to establish various resource recycling systems, which will not only make the operations work more efficiently but also form an intangible CE cultural atmosphere that can exert a subtle influence and implicit education to students. In other words, while participation in the CE practice is the responsibility of all members of the university, they will not suffer additional work stress or role load but can obtain many benefits in the process. In any case, the theoretical framework of CE-related university activities is a low-cost and high-profit way to promote the transition to a CE model.

\section{DISCUSSION AND CONCLUSIONS}

As an engine of knowledge and technology, universities can have a significant impact on the public's CE awareness

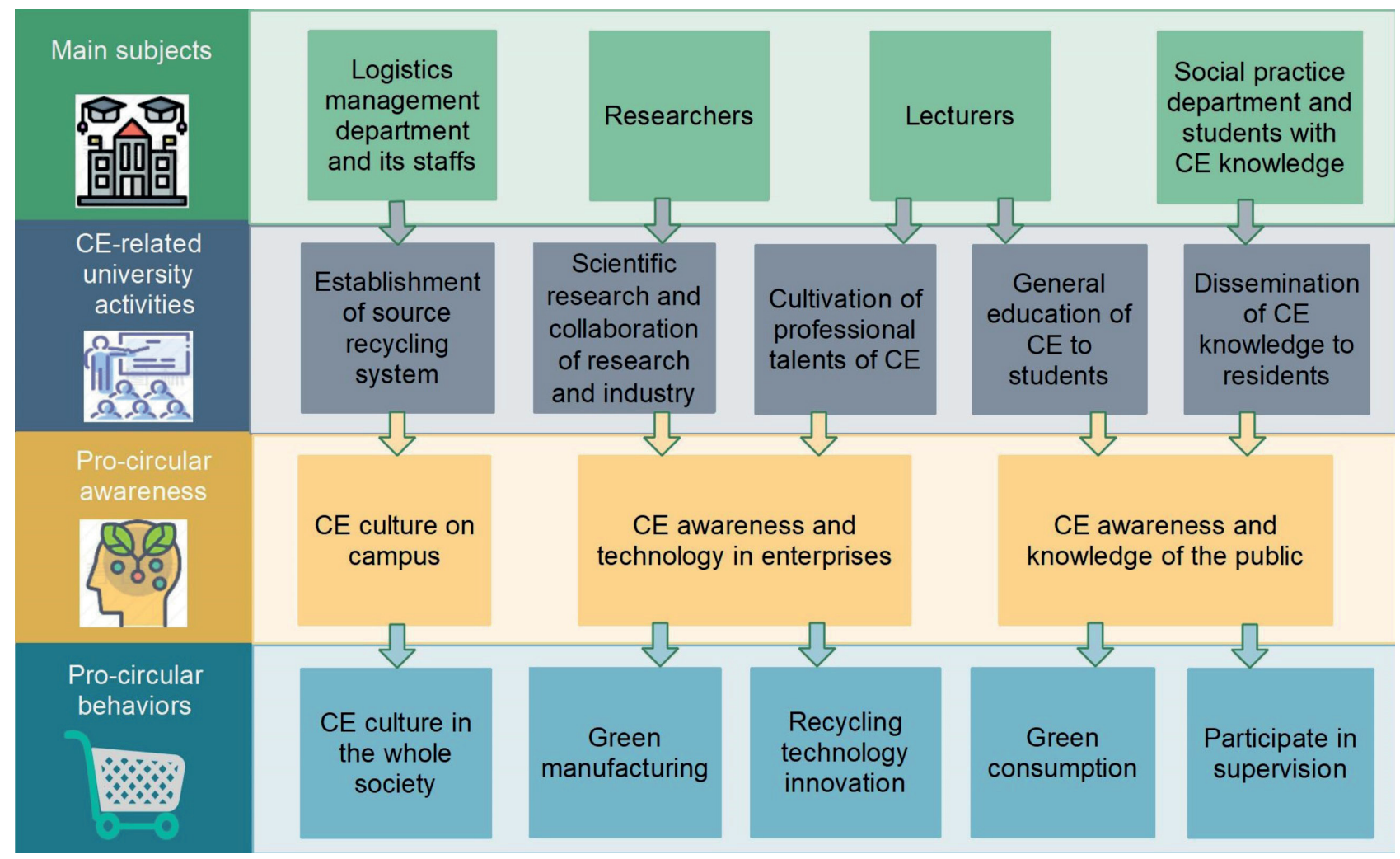

FIGURE 7: Theoretical framework of CE-related university activities toward the CE transition. 
and behavior of the workforce of tomorrow through $\mathrm{CE}$ education to drive the CE from theory to reality, and even raise standards for sustainable performance (Nunes et al., 2018). For early realization, this paper provided the definition of CE-related university assets as a novelty, which mainly refers to university assets involved in and which could be developed in the application of the 3Rs principles to contribute to universal CE policy goals. Further, we developed a theoretical framework for CE-related university activities based on the classification and attributes of CE-related university assets, such as non-profit status, technology innovation, education, propagation and efficient use of resources.

There have been many theoretical research and practical explorations of the contribution of higher education institutions to the CE. However, these implementations are fragmented, and separate operations or simple splicing cannot have an impressive impact on CE promotion, and may even cause friction and obstruction. We proposed a systematic theoretical framework for CE-related university activities, which integrates various $C E$ activities in a unified management system rather than simply patching them together, to achieve transformative learning and education to expand the university influence in the CE transition, which can make up for the deficiencies of previous studies. Additionally, this paper expounds the connotation and extension of the concept of CE-related university assets to make CE-related university activities concrete and close to reality, which is helpful for university implementation of the CE in practice.

In the theoretical framework of CE-related university activities, we proposed four kinds of activities toward the transition to a CE model on the basis of CE training for university faculty and staff. The first is scientific research CE-related activities, which take researchers as the main subject in the implementation and can provide CE technical support for enterprises based on scientific research CE-related assets. The second is education CE-related activities, which take lecturers as the central implementation subject who can cultivate CE professionals and implement general CE education for college students. The third is derived from the previous one, which takes college students as the main subject who can diffuse the CE concept to society through their routine social practices and other volunteer activities. The fourth is concrete CE practical activities with operations managers and staff members as the main subject, who could provide the reference for CE practice at the social level and contribute to the construction of CE culture in society based on operations CE-related assets.

Compared with the dimensions of sustainable universities (Cortese, 2003) and the pertinent themes of university CE assessment (Nunes et al., 2018), we provide a clearer explanation of the content of CE-related university activities in this CE theoretical framework, including a detailed process of activity implementation and specific responsible departments and subjects. It makes this framework more operable and feasible in practice, and can be used as a reference for other universities that would like to make contributions to the CE. However, it is a limitation that this framework leans on the implementer to exert their subjec- tive initiative to promote the various CE-related university activities from the bottom up. Thus, the effect and durability of implementation must be evaluated. Therefore, the formation of a university management model that transitions toward the CE transition must be investigated in future research to guarantee the implementation and development of this theoretical framework in universities, to more effectively foster the transition to a CE model.

\section{ACKNOWLEDGEMENTS}

This study is supported by Henan Institute of Science and Technology in China and Sumy National Agrarian University in Ukraine towards promoting recycling behavior. Further, this study is supported by the Erasmus+ Programme of the European Union within the project "Towards circular economy thinking \& ideation in Ukraine according to the EU action plan" (grant number 620966-EPP-1-2020).

\section{REFERENCES}

Amaral, L.P., Martins, N., Gouveia, G.B., 2015. Quest for a sustainable university: a review. International Journal of Sustainability in Higher Education 16 (2),1-16. http://dx.doi.org/10.1108/ IJSHE-02-2013-0017

American Sustainable Endowments Institute (ASEI), 2011. The College Sustainability Report Card. Available online: http://greenreportcard.org/index.html

Barros, M.V., Puglieri, F.N., Tesser, D.P., 2020. Sustainability at a Brazilian university: Developing environmentally sustainable practices and a life Cycle assessment case study. International Journal of Sustainability in Higher Education 21(5), 841-859. http://dx.doi. org/10.1108/IJSHE-10-2019-0309

Blake, J., Sterling, S., Goodson, I., 2013. Transformative learning for a sustainable future: An exploration of pedagogies for change at an alternative college. Sustainability 5(12), 5347-5372. http://dx.doi. org/10.3390/su5125347

Bugallo-Rodriguez, A., Vega-Marcote, P., 2020. Circular economy, sustainability and teacher training in a higher education institution. International Journal of Sustainability in Higher Education 21(7),1351-1366. https://dx.doi.org/10.1108/IJSHE-02-2020-0049

Burns, H., 2018. Thematic Analysis: Transformative Sustainability Education. Journal of Transformative Education 4, 277-279.

Coleman, K., Gould, R., 2019. Exploring just sustainability across the disciplines at one university. The Journal of Environmental Education 50(3), 223-237. http://dx.doi.org/10.1080/00958964.2019. 1582471

Cortese, A. D., 2003. The critical role of higher education in creating a sustainable future. Planning for Higher Education 31, 15-22.

Cui, X., Di, Y., Nan, N., Liu, X., Zhou, C., 2018. Practice and efficiency of resource recycling science and engineering specialty in the background of industry-education integration and school-enterprise cooperation. Recyclable Resources and Circular Economy 11(7), 7-10.

De Jesus, A., Mendonça, S., 2018. Lost in transition? Drivers and barriers in the eco-innovation road to the circular economy. Ecological Economics 145, 75-89. http://dx.doi.org/10.1016/j.ecolecon.2017.08.001

Dong, S., Yu, H., Li, Y., Li, Z., Li, F., Li, F., 2016. China industrial energy saving: analysis on driving factors of development of circular economy. Chinese Population, Resources and Environment 26(6), 27-34.

Du, R., 2016. Study on the circulation and sharing mode of learning resources in colleges and universities - A case study of seven universities in central China. Modern Economic Information 8, 406.

EMF. Ellen MacArthur Foundation, 2021. Universal circular economy policy goals: enabling the transition to scale. Available online: https://www.ellenmacarthurfoundation.org/publications/universal-circular-economy-policy-goals-enabling-the-transition-to-scale.

Findler, F., Schönherr, N., Lozano, R., Stacherl, B., 2019. Assessing the impacts of higher education institutions on sustainable development-An analysis of tools and indicators. Sustainability 11(1), 59. http://dx.doi.org/10.3390/su11010059 
Gaidabrus, N., Bilovodska, O., Sager, L., 2014. Logistic service in the innovative production distribution channels as its optimal structure factor. Actual Problems of Economics 11, 147-153.

Ghisellini, P., Cialani, C., Ulgiati, S., 2016. A review on circular economy: the expected transition to a balanced interplay of environmental and economic systems. Journal of Cleaner Production. 114, 11-32. https://dx.doi.org/10.1016/j.jclepro.2015.09.007

Guo, B., Geng, Y., Sterr, T., Zhu, Q., Liu, Y., 2016. Investigating public awareness on circular economy in western China: a case of Urumqi Midong. Journal of Cleaner Production 142(4), 2177-2186. http://dx.doi.org/10.1016/j.jclepro.2016.11.063

Guo, Y., 2014. Research on the recycling of college textbooks under the background of circular economy - A case study of Heilongjiang university of science and technology. Economist 10, 197-198.

Hopff, B., Nijhuis, S., Verhoef, L.A., 2019. New dimensions for circularity on campus - Framework for the application of circular principles in campus development. Sustainability 11(3), 627. http://dx.doi. org/10.3390/su11030627

Hu, B., Ji, B., 2017. Current situation of American circular economy standard formulation and its enlightenment to China. Value Engineering 36(31), 233-237. http://dx.doi.org/10.14018/j.cnki.cn13$1085 /$ n.2017.31.103

Jing, W., Zhang, L., 2014. Environmental regulation, opening to the outside world and the progress of green technology in Chinese industry. Economic Research Journal 49(9), 34-47.

Kirchherr, J., Piscicelli, L., 2019. Towards an education for the Circular Economy (ECE): Five teaching principles and a case study. Resources, Conservation and Recycling 150, 104406. http://dx.doi. org/10.1016/j.resconrec.2019.104406

Kirchherr, J., Reike, D., Hekkert, M., 2017. Conceptualizing the circular economy: An analysis of 114 definitions. Resources, Conservation and Recycling 127, 221-232. http://dx.doi.org/10.1016/j.resconrec.2017.09.005

Kopnina, H., 2019. Green-washing or best case practices? Using circular economy and Cradle to Cradle case studies in business education. Journal of Cleaner Production 219, 613-621. http://dx.doi. org/10.1016/j.jclepro.2019.02.005

Liu, Q., 2014. Policy characteristics and perfection ideas of developing circular economy in China: A perspective of ecological civilization. Ecological Economy 30(4), 27-34.

Liu, Q., 2015. The dynamic mechanism of science and technology under circular economy. Business 28, 263-264.

Liu, Q., Du, X., 2019. Experience discussion on Japan's circular economy development model. Modern Business 6, 182-183. http://dx. doi.org/10.14097/j.cnki.5392/2019.06.086

Ma R., 2020. Analysis on major problems and countermeasures against college's fixed assets management. Journal of Heilongjiang Institute of Technology 34(4), 77-80. http://dx.doi.org/10.19352/j.cnki. issn1671-4679.2020.04.015

Ma, C., 2016. Strategic deployment and leading plan of circular economy development. Renewable Resources and Circular Economy 9(8), 15-18

Morseletto P., Targets for a circular economy. Resources, Conservation and Recycling, Volume 153, 2020, 104553, https://doi. org/10.1016/j.resconrec.2019.104553

Mendoza, J.M.F., Gallego-Schmid, A., Azapagic, A., 2019. A methodological framework for the implementation of circular economy thinking in higher education institutions: Towards sustainable campus management. Journal of Cleaner Production 226, 831844. http://dx.doi.org/10.1016/j.jclepro.2019.04.060

NBSC. National Bureau of Statistics of China, 2020. China Statistical Yearbook 2020. Available online: http://www.stats.gov.cn/tjsj/ ndsj/2020/indexeh.htm

Nunes, B.T., Pollard, S.J.T., Burgess, P.J., Ellis, G., de los Rios, I.C., Charnley, F., 2018. University contributions to the Circular Economy: Professing the hidden curriculum. Sustainability 10(8), 2719. http://dx.doi.org/10.3390/su10082719

O'Neil, J.K., 2018. Transformative sustainability learning with a material-discursive ontology. Journal of Transformative Education 4, 365-387. https://doi.org/10.1177/1541344618792823

Orr, D.W., 2002. Four challenges of sustainability. Conservation Biology 16(6), 1457-1460.

PRC MOE. Ministry of Education of People's Republic of China, 1998. Higher Education Law. Available online: http://old.moe.gov.cn// publicfiles/business/htmlfiles/moe/moe_619/200407/1311.html
PRC NDRC. National Development and Reform Commission of People's Republic of China, 2015. Circular Economy Promotion Plan 2015. Available online: http://www.gov.cn/xinwen/2015-04/20/ content_2849620.htm

PRC SC. State Council of People's Republic of China, 2013. Circular Economy Development Strategy and Immediate Action Plan. Available online: http://www.gov.cn/zwgk/2013-02/05/content 2327562.htm

Qiao, G., Wang, T., 2013. On duty of care rules in British waste management and its enlightenment to China. China Population, Resources and Environment 23(1), 33-40.

Qu, D., Shevchenko, T. Yan, X., 2020. University curriculum education activities towards circular economy implementation. International Journal of Scientific and Technology Research 9(5), 200-206.

Qu, D., Shevchenko, T., 2019. Universities as a driving force for circular economy implementation in China. Bulletin of Sumy National Agrarian University 1(79), 14-20. https://dx.doi.org/10.32845/ bsnau.2019.1.3

Ranjbari, M., Saidani, M., Esfandabadi, Z.S., Peng, W., Lam, S.S., Aghbashlo, M., Quatraro, F., Tabatabaei, M., 2021. Two decades of research on waste management in the circular economy: Insights from bibliometric, text mining, and content analyses. J. Clean Prod. 128009. https://doi.org/10.1016/j.jclepro.2021.128009

Reike, D., Vermeulen, W.J.V., Witjes, S., 2018. The circular economy: New or refurbished as CE 3.0? - Exploring controversies in the conceptualization of the circular economy through a focus on history and resource value retention options. Resources, Conservation and Recycling 135, 246-264. https://dx.doi.org/10.1016/j. resconrec.2017.08.027

Rodriguez-Chueca, J., Molina-Garcia, A., Garcia-Aranda, C., Perez, J., Rodriguez, E., 2020. Understanding sustainability and the circular economy through flipped classroom and challenge-based learning: an innovative experience in engineering education in Spain Environmental Education Research 26(2), 238-252. http://dx.doi.or $\mathrm{g} / 10.1080 / 13504622.2019 .1705965$

Rokicki, T., Perkowska, A., Klepacki, B., Szczepaniuk, H., Szczepaniuk, E.K., Berezinski, S., Ziolkowska, P., 2020. The importance of higher education in the EU countries in achieving the objectives of the circular economy in the energy sector. Energies 13(17), 4407. http:// dx.doi.org/10.3390/en13174407

Rossi J., Bianchini A., Guarnieri P., 2020. Circular economy model en hanced by intelligent assets from industry 4.0: The proposition of an innovative tool to analyze case studies. Sustainability 12,7147 http://dx.doi.org/10.3390/su12177147

Saidani, M., Yannou, B., Leroy, Y., Cluzel, F., Kendall, A. 2019. A taxonomy of circular economy indicators. Journal of Cleaner Production, 207, 542-559. http://doi.org/10.1016/j.jclepro.2018.10.014

Saidani, M., Yannou, B., Leroy, Y., Cluzel, F., 2017. How to Assess Product Performance in the Circular Economy? Proposed Requirements for the Design of a Circularity Measurement Framework. Recycling 2(1) https://doi.org/10.3390/recycling2010006

Salguero-Puerta, L Leyva-Diaz, J.C., Cortes-Garcia, F.J., Molina-Moreno, V., 2019. Sustainability indicators concerning waste management for implementation of the circular economy model on the university of Lome (Togo) campus. International Journal of Environmental Research and Public Health 16(12), 2234. http://dx.doi. org/10.3390/ijerph16122234

Schroeder, P., Anggraeni, K., Weber, U., 2019. The relevance of circular economy practices to the sustainable development goals. Journal of Industrial Ecology 23(1), 77-95. http://dx.doi.org/10.1111/ jiec. 12732

Shen, P., 2016. Experience and enlightenment of circular economy development in developed countries. Environmental Protection 44(23), 68-71. http://dx.doi.org/10.14026/j.cnki.0253-9705.2016.23.016

Shevchenko T., Kronenberg J., Danko Y., Chovancová J. 2021. Exploring the circularity potential towards the multiple use of residual material to operationalize a circular economy model. Clean Technologies and Environmental Policy, 2 June. http://dx.doi.org/10.1007/ s10098-021-02100-4

Shevchenko, T., Kronenberg, J., 2020. Management of material and product circularity potential as an approach to operationalise circular economy. Progress in Industrial Ecology An International Journal 14(1), 30-57. http://dx.doi.org/10.1504/PIE.2020.105193

Shevchenko, T., Laitala, K., Danko, Y., 2019. Understanding Consumer E-Waste Recycling Behavior: Introducing a New Economic Incentive to Increase the Collection Rates, Sustainability 11, 2656. http://dx.doi.org/10.3390/su11092656 
Sokol, R.G., Shaughnessy, A.F., 2018. Making the most of continuing medical education: evidence of transformative learning during a course in evidence-based medicine and decision making. Journal of Continuing Education in the Health Professions 38(2), 102-109. http://dx.doi.org/10.1097/CEH.0000000000000199

Sterling, S., 2010-2011. Transformative Learning and Sustainability: Sketching the Conceptual Ground. Learning and Teaching in Higher Education 5, 17-33.

SDGKP. Sustainable Development Goals Knowledge Platform, 1992 Agenda 21. Available online: https://sustainabledevelopment.un.org/outcomedocuments/agenda21

Tan, X., Li, J., 2016. Benefit analysis of water recycling in universities - A case study of Guangzhou college of south China university of technology. Rural Economics and Technology 27(20), 53-54+63.

Telizhenko, O., Shevchenko, T., Mishenina, G., 2016. Sustainable management of the municipal solid waste resource potential in the context of product lifecycle continuity. Journal of Environmental Management and Tourism 16(4), 664-671. http://dx.doi. org/10.14505//jemt.v7.4(16).12

UNESCO. United Nations Educational Scientific and Cultural Organization, 2014. Global Action Programme on Education for Sustainable Development (2015-2019). Available online: https://en.unesco. org/globalactionprogrammeoneducation

UNESCO, 2015. Education 2030 Framework for Action. Available online: http://www.unesco.org/new/fileadmin/MULTIMEDIA/HQ/ED/ ED_new/pdf/FFA-ENG-270ct15.pdf

UNESCO, 2003. The United Nations Decade of Education for Sustainable Development (2005-2014). Available online: https://en.unesco. org/themes/education-sustainable-development/what-is-esd/undecade-of-esd

UI. Universitas Indonesia, 2019. UI GreenMetric World University Rankings 2019. Available online: http://greenmetric.ui.ac.id/overall-rankings-2019/

Wang, Z., 2014. Construction of long-term mechanism of college students' summer social practice. Ideological Education Research 3 , 83-86.
Weissbrodt, D.G., Winkler, M.K.H., Welts, G.F., 2020. Responsible science, engineering and education for water resource recovery and circularity. Environmental Science-water Research and Technology 6(8), 1952-1966. http://dx.doi.org/10.1039/d0ew00402b

Williams, I., Powell, L., 2019. Sustainable resource management by students at higher education institutions. Detritus 6, 11-24. http:// dx.doi.org/10.31025/2611-4135/2019.13813

Wysokińska, Z., 2016. The "New" environmental policy of the European Union: a path to development of a circular economy and mitigation of the negative effects of climate change. Comparative Economic Research 19(2), 57-73. http://dx.doi.org/10.1515/cer-2016-0013

Yin, Z., Shen, H., 2005. Construction of national scientific research system and development of research universities. Research and Development Management 4, 110-114. http://dx.doi.org/10.13581/j. cnki.rdm.2005.04.018

You, J., Wang P., 2016. Can environmental regulation promote R\&D towards green technology? An empirical study based on China's industrial sector. Economic Review 3, 26-38. http://dx.doi. org/10.19361/j.er.2016.03.03

Zhai, Y., 2017. Research on circular economy and legislation of circular economy. Journal of Shanghai University of Political Science \& Law (The Rule of Law Forum) 32(6), 11-20.

Zhang H., Zheng X., Liu Y., Li J., Lu H., 2020. Information construction of the whole life cycle of state-owned assets in universities in the era of big data. Research and Exploration in Laboratory 39(10),280-284.

Zhang, A, Venkatesh, V.G., Liu, Y., Wan, M, Qu, T, Huisingh, D. 2019. Barriers to smart waste management for a circular economy in China. Journal of Cleaner Production 240, 1-12. http://dx.doi. org/10.1016/j.jclepro.2019.118198

Zhao, J., Zhang, R., 2012. Thoughts on promoting cultural inheritance and innovation in universities. Ideological and Political Education Research 28(2), 17-20. http://dx.doi.org/10.15938/j.cnki. iper.2012.02.023

Zhu, D., 2017. A review of circular economy development in European countries over the last decade and its implications to deepen Chinese's circular economy. Chinese Population, Resources and Environment 27(8), 9-16. 